\title{
Nutritional Status in Children with Chronic Renal Failure on Hemodialysis
}

\author{
Moushira Erfan Zaki ${ }^{1}$, Mona Mamdouh Hassan², Hafez Mahmoud Bazaraa², Hany Fathy Ahmed ${ }^{1}$, Ahmed Mohamed Mahmoud \\ Badr $^{2}$ \\ ${ }^{1}$ Biological Anthropology Department, Medical Research Division, National Research Centre, Cairo, Egypt; ${ }^{2}$ Department of \\ Pediatrics, Faculty of Medicine, Cairo University, Cairo, Egypt
}

\author{
Citation: Zaki ME, Hassan MM, Bazaraa HM, \\ Ahmed HF, Badr AMM. Nutritional Status in \\ Children with Chronic Renal Failure on \\ Hemodialysis. Maced J Med Sci. 2012 Oct 15: \\ 5(3):296-301. http://dx.doi.org/10.3889/ \\ MJMS.1957-5773.2012.0234. \\ Key words: Nutritional status; chronic renal \\ failure; Egyptian children. \\ Correspondence: Prof. Moushira Erfan Zaki. \\ Biological Anthropology Department, Medical \\ Research Division, National Research Centre, \\ Egypt. E-mail: moushiraz@yahoo.com \\ Received: 25-Jan-2012; Revised: 20-Mar-2012; \\ Accepted: 20-Mar-2012; Online first: 21-Aug-2012 \\ Copyright: (c) 2012 Zaki ME. This is an open- \\ access article distributed under the terms of the \\ Creative Commons Attribution License, which \\ permits unrestricted use, distribution, and \\ reproduction in any medium, provided the origina \\ author and source are credited. \\ Competing Interests: The author have declared \\ that no competing interests exist.
}

\section{Abstract}

Background and Aim: Growth retardation is still an important manifestation of children with chronic renal failure (CRF). The aim of this study is to evaluate the growth in relation to nutritional status in Egyptian children with CRF on hemodialysis.

Subjects and Methods: The study included 30 Egyptian children above the age of six years on regular haemodialysis at the Haemodialysis Unit of the Centre of Pediatric Nephrology and Transplantation of Cairo University. Anthropometry, biochemical parameters and dietary intake were measured. Anthropometric measurements were expressed as z - scores.

Results: Data shows that height was the most affected anthropometric parameter. Short stature in CRF is proportionate and body weight is less affected than height. Dietary analysis showed that $76.7 \%$ of patients had recommended dietary allowance of calories. Height z-score showed a significant positive correlation with caloric intake. On the other hand, the protein intake showed a significant positive correlation with blood urea nitrogen and a significant negative correlation with serum bicarbonate.

Conclusions: Nutritional assessment is essential to the management of children with CRF. Anthropometry is a sensitive indicator of the nutritional status. The study recommends avoiding excessive protein intake to prevent metabolic acidosis and accumulation of toxic nitrogen waste products.

\section{Introduction}

Chronic kidney disease (CKD) refers to a condition related to irreversible kidney damage that can further progress to end stage renal disease (ESRD). CKD is a major public health problem worldwide. Most of the existing data on the epidemiology of CKD during childhood concentrates on the late and more severe stages of renal impairment and are not population based in nature [1]. The incidence in of CKD in Europe was consistent, being around 11-12 per million of the age- related population [2]. The epidemiology of end-stage renal disease (ESRD) in Egypt has never been examined on a national scale [3].

The incidence rate of severe pre-terminal CKD in Lorraine (France) has been estimated as 7.5 per year per million of the age-related population (MARP) in children younger than 16 years; the prevalence rate ranged from 29.4 to 54 per MARP [4]. A number of factors influence incidence and prevalence rate variability 
of childhood. Factors such as racial and ethnic distribution, type of prevalent renal disease, and quality of medical care available for preterminal CKD patients have a significant impact on patient outcome [5]. Malnutrition is recognized to be a serious and common complication of chronic kidney disease (CKD) and is associated with increased morbidity and mortality [6]. Growth failure is a common and significant clinical problem in children with chronic renal failure. Affected children exhibit a range of potentially serious medical and psychological complications, as well as increased mortality [7]. The most common causes of hospitalization in these patients are infections, possibly related to their poor nutritional status. Therefore, although poor growth is unlikely to be the cause of this increased morbidity, growth failure may be a marker of untoward events [8]. The etiology of growth failure in these children is multifactorial, age at onset of the disease, primary renal disease, severity of CRF, hormonal resistance, anemia, metabolic acidosis, malnutrition, renal osteodystrophy, and inadequate dialysis are all implicated [9].

The aim of this study is to evaluate the growth in relation to nutritional status in Egyptian children with CRF on hemodialysis.

\section{Subjects and Methods}

This cross sectional study was carried out at the Haemodialysis Unit of the Centre of Pediatric Nephrology and Transplantation (CPNT) Hospital of Cairo University, in the period from January till June 2005. The study included 30 Egyptian children above the age of six years with end-stage renal disease on regular haemodialysis. Patients met the following inclusion criteria: GFR $\leq 60$ $\mathrm{ml} / \mathrm{min}$ per $1.73 \mathrm{~m}^{2}$; on regular hemodialysis; their age ranged from 6 to 13 years, 20\% of cases had anuria. The study excludes patients who were received corticosteroid or growth hormone treatment. Primary causes of CRF were chronic interstitial nephritis, posterior urethral valve and glomerulonephritis . A formal consent letter from the parents of each child was obtained after explaining to them the whole procedure. The study was approved by the Ethical Committee of the Cairo University; (CPNT) Hospital. Clinical examination was done for all cases. was All children were subjected to full history with special emphasis on age at onset and duration of the disease. Dietary assessment of a 3 day dietary diary was taken [10] All nutrients were computer analysed (qualitatively/quantitatively) using Food Composition Tables for Egypt [11]. Protein and calories intakes were calculated and expressed as a percentage of the recommended dietary allowance of protein and calories for CHD as recommended by NKF- K / DOQI [12]. The RDA of protein for CHD patients was that for children of the same chronological age, with an additional increment of $0.4 \mathrm{~g} / \mathrm{kg}$ per day. Anthropometric measurements were taken after three months of dietary assessment. The anthropometric measurements and instruments used followed the International Biological Programmer (IBP) [13]. Body weight, height, sitting height, arm span, mid upper arm circumference, triceps and subscapular skin folds were measured. To avoid the effect of oedema on expression of the weight, weight measurements were obtained in a euvolemic state (dry weight, or euvolemic weight). Dry weight was estimated by examining the patient for edema and jugular venous distention and by considering other factors such as blood pressure and response to fluid removal. Weight was measured using a sensitive platform weighing scale, with minimal clothes. The child was standing in the center of the scale platform, and then weight was recorded to the nearest $0.1 \mathrm{~kg}$. Anthropometric are expressed as standard deviation scores (z-score) for age and sex specific values, using the general formula, $\mathrm{z}$ - score $=(\mathrm{X}-\mathrm{Xi}) /$ Sdi, where $\mathrm{X}$ is the individual patient value; $X i$ the mean value for the normal reference Egyptian population; and Sdi the standard deviation from normal value. Growth evaluation was based on the Egyptian Growth Reference Data [14]. All patients were on regular HD for three to four times a week based on fluid and electrolyte balance.

Dialysis adequacy assessment using fractional urea clearance expressed as single pool $\mathrm{Kt} / \mathrm{V}$ was calculated [15]. Predialysis serum blood urea nitrogen (BUN) and arterial blood gases were measured.

Datawas analyzed by SPSS (Statistical Package for Social Sciences) under Windows (version 16). The Kolmogorov-Smirnov test was used to check for normality in the continuous variables All results were expressed as mean \pm SD. Comparisons between groups were made using independent t-tests. Pearson correlation coefficient analysis assessed correlations between continuous variables. Significance was assumed for $p$ values of less than 0.05 .

\section{Results}

The present study included 30 children, 16 boys (53.3\%) and 14 girls (47.7\%) with chronic renal failure on regular hemodialysis. Their age ranged from 6.4-13.8 years with a mean of 10.5 years. Table 1 presents mean 
Table 1: The age at onset, duration, caloric and protein intake in children with CRF.

\begin{tabular}{lccr}
\hline & Mean \pm SD & Minimum & \multirow{2}{*}{ Maximum } \\
\hline Age at onset of the disease ( years) & $7.5 \pm 1.72$ & 3.4 & 10.3 \\
Duration of the disease ( years) & $2.9 \pm 1.34$ & 0.8 & 5.5 \\
Caloric intake \% of RDA of calories* & $91.75 \pm 14.50$ & 70.0 & 130.0 \\
Protein intake \% of RDA of protein * & $139.3 \pm 23.07$ & 95.0 & 200.0 \\
\hline${ }^{*}$ Caloric and protein intake expressed as a percentage (\%) of the RDA of calories and protein
\end{tabular}
for children with CRF on hemodialysis of the same chronological age.

the age at onset of the disease and disease duration, the period since CRF was diagnosed, caloric and protein intake, expressed as percentage.

Table 2 shows clinical and laboratory characteristics of children with CRF. The anthropometric measurements of the study group were expressed in zscore. Results revealed that height was the most affected anthropometric parameter, as $83.3 \%$ of the patient were short (height z- below -2), and the height $z$ - score ranged between -0.6 and -7.1 , with a mean of -3.66 . In addition, the mean upper segment/ lower segment ratio was 1.1,

Table 2: Clinical and laboratory characteristics of children with CRF.

\begin{tabular}{lccccc}
\hline & \multirow{2}{*}{ Mean } & \multicolumn{2}{c}{$95 \% \mathrm{Cl}$} & \multirow{2}{*}{ Minimum } & \multirow{2}{*}{ Maximum } \\
\hline Height Z-score & -3.66 & -4.26 & -3.06 & -7.1 & -0.6 \\
weight Z-score & -1.98 & -2.14 & -1.82 & -3 & -1.1 \\
Body mass index Z-score & -1.01 & -1.23 & -0.79 & -1.9 & 0.3 \\
Mid upper arm circumference Z-score & -1.55 & -3.1 & -0.2 & -1.79 & -1.31 \\
Triceps skin fold thickness Z-score & -0.98 & -2.2 & 0.4 & -1.16 & -0.79 \\
Subscapular skin fold thickness Z-score & -0.84 & -2.1 & 0.7 & -1.04 & -0.64 \\
Arm span / height ratio & 0.99 & 0.98 & 1.01 & 0.91 & 1.09 \\
Upper segment/ lower segment ratio & 1.1 & 1.1 & 1.21 & 0.95 & 1.54 \\
Serum bicarbonate (mmol/L) & 17.49 & 13.2 & 21.6 & 12.8 & 22.1 \\
BUN (predialysis) (mg/dl) & 57.99 & 36 & 82.9 & 35 & 84.6 \\
Kt/V & 1.493 & 1.3 & 1.9 & 1.2 & 2 \\
\hline
\end{tabular}

and the mean arm span / height ratio was 1 indicating that short stature in CRF is proportionate. Body weight is less affected than height, as body weight $z$ - score of $46.7 \%$ of patients were below -2 , with a mean of -1.98 . Mean z-scores of mid upper arm circumference, triceps and subscapular skinfolds thicknesses were slightly reduced. Patients had serum bicarbonate level below the normal level $(22 \mathrm{mmol} / \mathrm{L})$. The $\mathrm{Kt} / \mathrm{V}$ is a measure of the amount of plasma cleared of urea $(\mathrm{K} \times \mathrm{t})$ divided by

Table 3: Correlations between duration of disease, dietary intake and anthropometric measurements in children with CRF.

\begin{tabular}{lccc}
\hline & $\begin{array}{c}\text { Duration of } \\
\text { disease }\end{array}$ & $\begin{array}{c}\text { Caloric } \\
\text { in take }\end{array}$ & $\begin{array}{c}\text { Protein } \\
\text { intake }\end{array}$ \\
\hline Ht Z-score & $-.632^{* *}$ & $.377^{*}$ & -0.21 \\
Wt Z-score & $-.496^{* *}$ & $.673^{* *}$ & -0.3 \\
BMI Z-score & 0.138 & $.404^{*}$ & -0.26 \\
Mid upper arm circumference Z-score & -0.053 & $.457^{*}$ & -0.3 \\
Triceps skin fold thickness Z-score & 0.257 & 0.188 & -0.29 \\
Subscapular skin fold thickness Z-score & 0.36 & 0.178 & -0.22 \\
\hline
\end{tabular}

the urea distribution volume $(\mathrm{V})$. Patients had $\mathrm{Kt} / \mathrm{V}$ ranged between 1.2 and 2, with a mean of 1.49. Mean predialysis BUN was $57.99 \mathrm{mg} / \mathrm{dl}$, ranged between 36 and $82.9 \mathrm{mg} / \mathrm{dl}$.

Significant positive correlations were found between protein intake and z-scores of height, weight,

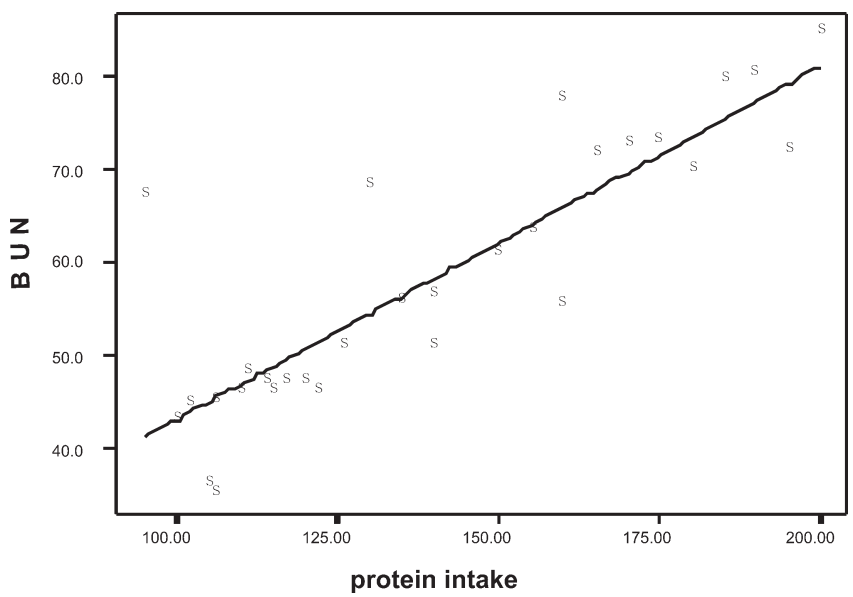

Figure 1: Correlation between protein intake and BUN in children with CRF on haemodialysis.

BMI and mid upper arm circumference. Moreover, significant negative correlations were found between disease duration and z-score of height and weight (Table 3).

Figures 1 and 2 demonstrate the correlations between protein intake and BUN as well as between protein intake and serum bicarbonate level, respectively.

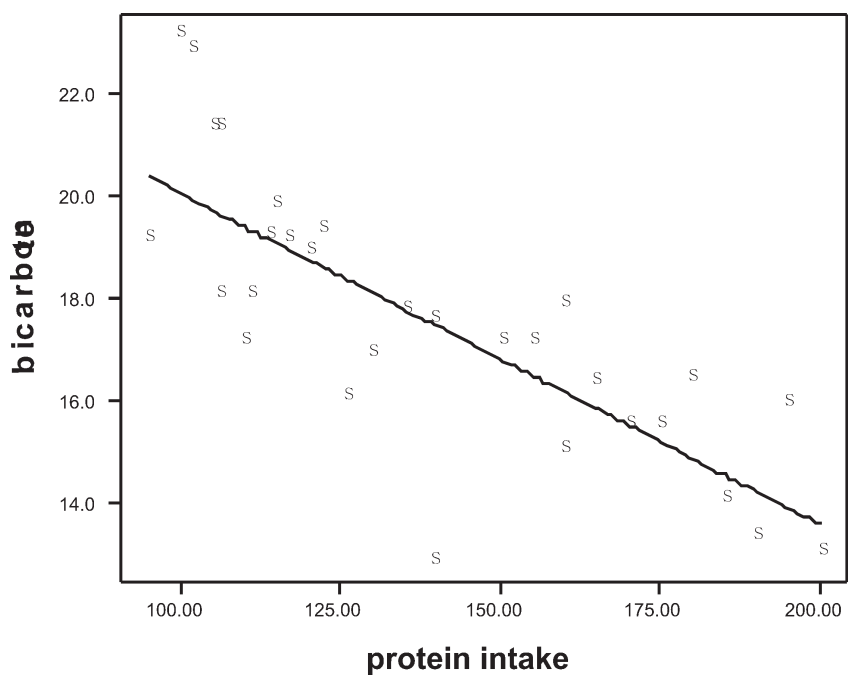

Figure 2: Correlation between protein intake and serum bicarbonate in children with CRF on haemodialysis. 
Protein intake showed significant positive correlation with BUN and significant negative correlation with serum bicarbonate level.

\section{Discussion}

The present work demonstrates that height is the most severely affected anthropometric parameter in children with CRF on dialysis. Our results agrees with those of another Egyptian study done on 64 Egyptian children with CRF on conservative treatment with an age range of $0.5-21$ years which reported that the mean height z- score was -3.7 in the Egyptian children with CRF [16]. On the other hand, data from developed countries generally show less severe height affection. The data on growth of 2,329 children in the North American Pediatric Renal Transplant Cooperative Study (NAPRTCS), showed that $36.6 \%, 47.0 \%$, and $43.0 \%$ of children with chronic renal insufficiency (CRI), dialysis, and transplantation, respectively, have short stature, and the mean height $z$ - score were $-2.54,-1.95$, and 1.67 for children aged 0 to 1 years, 2 to 5 years and 6 to 12 years, respectively [17]. Most of patients were treated with hemodialysis.

In the present study, the mean upper segment/ lower segment ratio was 1.1, and the mean arm span / height ratio was 1 indicating that short stature in CRF is proportionate. This is in agreement with another study stated that children with severe growth retardation due to CRF maintain normal body proportions in spite of their chronic disease [18]. In contrast with another study demonstrated low ratio in length of trunk to limb in patients with CRF, suggesting a disproportionately greater effect of disease and/or treatment on spinal growth [19]. The body weight is less affected than height in the present study. This agrees with other studies reported that no significant deficit in body weight has been found in studies of children with CKD [20]. Also, the mean z-score of mid upper arm circumference triceps and subscapular skinfold thicknesses were slightly reduced. Mild-to-moderate deficits in triceps-skinfold thickness have been reported in children with CKD [21]. The Kidney Disease Outcome Quality Initiative (K/DOQI) Clinical Practice Guidelines for Nutrition in Chronic Renal Failure stated that no single measure provides a complete picture of nutritional status. Consequently, many different measures are recommended, with the implication that the treating team will integrate the results into a cogent assessment of nutritional status [22].

The NKF-K/DOQI (2000) recommended that initial prescribed energy intake for children treated with maintenance hemodialysis or peritoneal dialysis should be at the recommended dietary allowance (RDA) level for chronological age, since there is no evidence that children on dialysis require a higher RDA than do healthy children [12]. Modifications should then be made depending upon the child's response. Inadequate food intake in children with CKD is secondary to multiple factors including anorexia, altered taste sensation, nausea, vomiting, emotional distress, intercurrent illness, unpalatable prescribed diets, and impaired ability to procure food because of socioeconomic situation. In the present study, caloric intake of the patients ranged between 70 and $130 \%$ of the RDA of calories with a mean of $91.75 \%, 23.3 \%$ only of the patients received adequate energy intake exceeding $100 \%$ RDA; whereas, the energy intake of the rest $(76.7 \%)$ was below the $100 \%$ RDA; but still above $70 \%$ of RDA. Regarding protein intake, $96.7 \%$ received adequate protein intake exceeding $100 \%$ RDA; while, the protein intake of the rest (3.3\%) was below the $100 \%$ RDA. Thus, the majority of patients need improvement in the eating patterns, as compared with healthy children diet reported in the National Egyptian survey, Diet, Nutrition and Prevention of Chronic Non-communicable Diseases [23].

In addition, height z-score showed a significant positive correlation with caloric intake, and the mean height $z$-score of patient who had received $\geq 100 \%$ of the RDA of calories was -2.8 while the height $z$-score of patients who had received $<100 \%$ of the RDA of calories was -3.9. Former studies reported that in CRF restoration of normal energy requirements to $100 \%$ of the RDA of calories allows for catch-up growth in children less than 2 years and shows some benefit in older children. Nevertheless, other studies showed no change in height z-score after increasing caloric supplementation to patients above the age of 3 years [24-26]. Infants with CRF do not always grow well despite good nutrition and adequate metabolic and clinical control [27]. The present study showed significant positive correlation between protein intake and BUN (predialysis), and significant negative correlation between protein intake and bicarbonate level. Sodium bicarbonate is effective for the treatment of metabolic acidosis but it should be prescribed judiciously, owing to the risk of sodium loading and consequent volume expansion and hypertension. Bicarbonate therapy is typical when serum bicarbonate levels are less than $22 \mathrm{mmol} / \mathrm{L}$. An excessive energy intake may induce hyperlipidaemia and hyperinsulinism. It is also associated with high leptin levels, which may contribute to lack of appetite. Children on dialysis should 
have their initial dietary protein intake based on the RDA for chronological age, with an additional increment of 0.4 $\mathrm{g} / \mathrm{kg}$ per day for patients on haemodialysis, or their anticipated peritoneal losses for children on peritoneal dialysis. This recommendation is based on work done in adults on haemodialysis who failed to maintain nitrogen balance on $1.1 \mathrm{~g}$ protein/kg/ day (NKF-K/DOQI, 2000). An excessive protein intake should also be avoided in children on dialysis, to prevent metabolic acidosis, hyperphosphataemia and the accumulation of toxic nitrogen waste products [28].

In the present study, Kt/ $\mathrm{V}$ ranged between 1.2 and 2, with a mean of 1.49. The NKF-DOQI (2006) stated that dialysis adequacy for both adult and pediatric patients undergoing $\mathrm{HD}$ are achieved with minimum $\mathrm{Kt} / \mathrm{V}$ prescription of 1.2 for a thrice weekly hemodialysis schedule [29]. This study showed no significant correlation between height $\mathrm{z}$-score and $\mathrm{Kt} / \mathrm{V}$. This is in accordance with studies stated that although adequate dialysis needs to be achieved in order to ensure good protein intake, high dialysis doses $(<1.6)$ are of no further benefit [30]. This, however, doesn't exclude the possibility that a Kt/V less than 1.2 would be associated with poor growth. On the other hand, height z-score showed significant negative correlation with the disease duration. This in agreement with study stated that the earlier the onset of kidney disease, the more severe the growth disturbance [31]. Thus, identification of nutrition and growth abnormalities, followed by fast intervention with nutritional supplements might allow correction of deficits.

\section{Acknowledgements}

The authors are grateful to Prof. Dr. Fatina Ibrahim Fadil Prof. of Pediatrics, Faculity of Medicine, Cairo University and all the team of the haemodialysis unit of the Center of Pediatric Nephrology and Transplantation of Cairo University for their great help and cooperation.

\section{References}

1. Fivush BA, Jabs K, Neu AM, Sullivan EK, Feld L, Kohaut E, Fine R. Chronic renal insufficiency in children and adolescents: the 1996 annual report of NAPRTCS. Pediatr Nephrol. 1998;12:328-337.

2. Harambat J, van Stralen KJ, Kim JJ, Tizard EJ Epidemiology of chronic kidney disease in children. Pediatr Nephrol. 2012; 27:363-73.
3. Afifi A, Karim MA. Renal replacement therapy in Egypt: first annual report of the Egyptian Society of Nephrology, 1996. East Mediterr Health J. 1999; 5:1023-9.

4. Deleau J, Andre JL, Briancon S, Musse JP. Chronic renal failure in children: an epidemiological survey in Lorraine (France). Pediatr Nephrol. 1994;8:472-476.

5. Moosa MR and Kidd M. The dangers of rationing dialysis treatment: the dilemma facing a developing country. Kidney Int. 2006;70:1107-1114.

6. Wong CS, Gipson DS, Gillen DL, Emerson S, Koepsell T, Sherrard DJ, Watkins SL, Stehman-Breen C. Anthropometric measures and risk of death in children with end-stage renal disease. Am J Kidney Dis. 2000;36(4):811-819.

7. Furth SL, Hwang W, Yang C, Neu AM, Fivush BA, Powe NR. Growth failure, risk of hospitalization and death for children with end-stage renal disease. Pediatr Nephrol. 2002; 17:450455.

8. Stefanidis CJ and Klaus G. Growth of prepubertal children on dialysis. Pediatr Nephrol. 2007; 22:1251-1259.

9. Mahan JD and Warady BA. Assessment and treatment of short stature in pediatric patients with chronic kidney disease: a consensus statement. Pediatr Nephrol. 2006; 21:917-930.

10. Foster and Leonard Foster BJ and Leonard MB. Measuring nutritional status in children with chronic kidney disease. Am J Clin Nutr. 2004; 80:801-14.

11. National Nutrition Institute Food Composition Tables for Egypt. Cairo, Egypt, 2006.

12. National Kidney Foundation. Kidney Disease Outcomes Quality Initiative (NKF- K/DOQI). Clinical practice guidelines for nutrition in CRF. Am J Kidney Dis. 2000; 35(Suppl 2):S140.

13. Hiernaux J, Tanner JM. Growth and physique: anthropometry. In: Weiner JS, Lourie JA, eds. Human biology, a guide to field methods. Philadelphia, FA Davis Company, $1969 ; 2-42$

14. Ghalli I, Salah N, Hussien F, Ze M, El-Ruby M, Mazen I, Sabry M, El-Razik AM, Saad M, Hossney L, Ismaail S, ElDayem AS, et al. Egyptian growth curves for infants, children and adolescents. In: Satorio A, Buckler JMH, Marazzi N, Crecere nel mondo. Ferring Publisher, Italy, 2008.

15. Daugirdas JT. Second generation logarithmic estimates of single-pool variable volume $\mathrm{Kt} / \mathrm{V}$ : An analysis of error. J Am Soc Nephrol.1993; 4:1205-1213.

16. Zahrane M, Fawaz L, Gamal N, EL Khawaga A, Nesseim L. Auxological and Laboratory Parameters of Growth in Egyptian Children with CRF on Conservative Therapy. Kasr El- Aini Medical Journal. 2002; 8: 221-240.

17. North American Pediatric Renal Transplant Cooperative 
Study 2006 Annual report. Renal transplantation, dialysis, chronic renal insufficiency. Available at: http://web.emmes.com/ study/ped/annlrept/annlrept 2006.pdf

18. De Graaff LC, Mulder PG, Hokken-Koelega AC. Body proportions before and during growth hormone therapy in children with chronic renal failure. Pediatr Nephrol. 2003; 18:679-68.

19. Qayyum N, Alcocer L, Maxwell H, Beattie TJ, Murphy AV, Ramage IJ, Ahmed SF. Skeletal disproportion in children with chronic renal disease. Horm Res. 2003; 60:221-226.

20. Abitbol CL, Warady BA, Massie MD, Baluarte $\mathrm{HJ}$, Fleischman LE, Geary DF, Kaiser BA, McEnery PT, Chan JC. Linear growth and anthropometric and nutritional measurements in children with mild to moderate renal insufficiency: a report of the Growth Failure in Children with Renal Diseases Study. J Pediatr. 1990 ; 116:S46-54.

21. Salusky IB, Fine RN, Nelson P, Blumenkrantz MJ, Kopple JD. Nutritional status of children undergoing continuous ambulatory peritoneal dialysis. Am J Clin Nutr. 1983; 38:599_ 611.

22. National Kidney Foundation. Kidney Disease Outcomes Quality Initiative (NKF- K/DOQI). Clinical practice guidelines for nutrition in CRF. Am J Kidney Dis. 2000; 35:S1-40.

23. Diet, nutrition and prevention of chronic non-communicable deseases), 2008: Final report, National survey of National Nutrition Institute, Egypt, 2004-2008.

24. Rees $L$ and Shaw V. Nutrition in children with CRF and on dialysis. Pediatr Nephrol. 2007; 22:1689-702.
25. Ledermann SE, Shaw V, Trompeter RS. Long-term enteral nutrition in infants and young children with chronic renal failure. Pediatr Nephrol. 1999; 13:870-875.

26. Ellis EN, Yiu V, Harley F, Donaldson LA, Hand M, Warady BA, Wood EG; North American Pediatric Renal Transplant Cooperative Study. The impact of supplemental feeding in young children on dialysis: a report of the North American Pediatric Renal Transplant Cooperative Study. Pediatr Nephrol. 2001; 16:404- 408 .

27. Santos F, M. Moreno M, Neto A, Ariceta G, Vara J, Alonso A, Alberto Bueno A, Afonso A, Correia A, Muley R, Barrios V, Go' mez C and Argente J. Improvement in Growth After 1 Year of Growth Hormone Therapy in Well-Nourished Infants with Growth Retardation Secondary to Chronic Renal Failure: Results of a Multicenter, Controlled, Randomized, Open Clinical Trial. Clin J Am Soc Nephrol. 2010; 5: 1190-1197.

28. Wingen $A M$ and Mehls $O$. Nutrition in children with preterminal chronic renal failure. Myth or important therapeutic aid? Pediatr Nephrol. 2002;17:111-120.

29. National Kidney Foundation. Kidney Disease Outcomes Quality Initiative (NKF- K/DOQI): Clinical practice guidelines for hemodialysis adequacy, 2006.

30. Marsenic O, Peco-Antic A, Jovanovic O. Effect of dialysis dose on nutritional status of children on chronic hemodialysis. Nephron. 2001; 88:273-275.

31. Stefanidis CJ. Growth and nutrition of children with chronic renal failure. Turk J Pediatr. 2005; 47 : 9-12. 